\title{
Experiences of Workers at Domestic Violence Shelters in South Korea
}

\author{
Hee-Jin Kim, Ok-Chai Choi* \\ Department of Social Welfare, Jeonbuk National University, South Korea \\ *Corresponding author: Pro.
}

\begin{abstract}
.
In South Korea, a lot of research has been conducted about domestic violence victims, who are residents of domestic violence shelters, but there are very few studies about the workers who supporting these victims and these studies are mostly quantitative. Workers at these shelters communicate closely with victims. As they protect them, they are also exposed to secondary trauma and various threats. Therefore, it is necessary to take a closer look at the experiences of these workers as well. In this study, interviews were conducted with six employees working at domestic violence shelters in South Korea. They were asked the research question "What are the experiences of domestic violence shelter workers?" and a within-case and cross-case analysis of qualitative case studies with collected date was conducted. Through the within-case analysis, we looked at the individual contexts of the study participants. The cross-cases analysis resulted in nine topics: Empathy or an objective approach, Cause of conflict as well as arbitrator, Difficulty in being objective, Guilt for not providing enough support, Exposure to danger, Supporter or an obstruction, Poor work condition and lack of respect, Motivation to work, Facilitator of change. On the basis of these, I have recommended that a system is needed that guarantees the safety of workers of in the shelter, establishment of a smooth cooperative system with relevant agencies, practical programs to deal with secondary trauma and exhaustion, treatment of workers and improvement of working conditions.
\end{abstract}

Keywords: experience of a worker; domestic violence; domestic violence shelter; case study 


\section{Introduction}

For a long time, families were considered as private spaces, and the awareness that domestic violence issues should be viewed with social interest was quite low, in South Korea(Bae \& Seo, 2017). In line with the global trend, however, Korean Women's Hot Line was established in 1983, and support was offered for victims of domestic and sexual violence. However, domestic violence occurs within the family, and these victims have to step out of their home, the place that they live in, to escape the violence. The Korean Women's Hot Line began operating its first domestic violence shelter in 1987 after renovating its office. As of 2018 there are about 66 domestic violence shelters in South Korea(The Ministry of Gender Equality and Family of Korea, 2019, A).

As the number of domestic violence shelters and the number of victims in these shelters has increased, research is focusing on the experiences of the victims, coping with the experience(Lee, 1997; So \& Jeong, 2002), exclusion from society(Lee \& Park, 2010), reporting domestic violence(Jang \& Kim, 2005), and child-rearing(Park, 2014; Yang \& Kim, 2009). Also support measures available for the victims are being actively discussed. On the other hand, research on workers who support these victims and who are exposed to secondary trauma and other risks, is relatively poor.

In conselling and supporting the victims, the workers also suffer psychological difficulties as they experience their pain, anxiety and fear(Yoon, 2009; Lee \& Yoo, 2010). In particular, the shelters are the living spaces of victims, and the workers are in direct contact with them and are exposed to many dangers like (threats from perpetrators) while protecting the victim. In fact, there have been instances in the past when domestic violence perpetrators have occasionally broken into or come to shelters in South Korea.

Accordingly, this study tries to take a closer look at their experiences with the research question, "What are the experiences of domestic violence shelter workers?". The purpose of this study is to understand the actual condition of workers at these shelters and to discuss ways to support them.

\subsection{Domestic violence shelters in South Korea}

Based on the "Act on Prevention of Domestic Violence and Protection of Victims", there is a Women's emergency hot-line 1366, and domestic violence counselling centers and shelters have been established in South Korea. The first domestic violence shelters were established in 1987 in temporary spaces created by the Korean Women's Hot Line. A total of 66 shelters are now operational with 46 general facilities and 20 family protection facilities. There are two facilities for the disabled and three facilities that offer medium and long-term shelter(The Ministry of Gender Equality and Family of Korea, 2019, A). The support provided at these shelters in listed in Table 1.

Table 1: Support in domestic violence shelters

\begin{tabular}{|c|r|}
\hline Basic support & $\begin{array}{c}\text { Providing meals and a sleeping places, legal and psychological } \\
\text { counselling, medical support, cooperation and support requests, etc. }\end{array}$ \\
\hline
\end{tabular}




\section{8-20 October, 2019 BUDAPEST, HUNGARY}

\begin{tabular}{|c|c|}
\hline Support for self-reliance & $\begin{array}{l}\square \text { Active support if one wants to work and prepare for being self reliant } \\
\text { after leaving the shelter (through link ups with local community } \\
\text { resources). }\end{array}$ \\
\hline $\begin{array}{l}\text { Privacy and special } \\
\text { protection for victims }\end{array}$ & $\begin{array}{l}\checkmark \text { Ask the police to cooperate in the event of a meeting between a } \\
\text { domestic violence assailant and the victim. } \\
\checkmark \text { Civil servants who have jobs related to domestic violence shelters are } \\
\text { not allowed to divulge information about the victims. }\end{array}$ \\
\hline $\begin{array}{l}\text { Support for school life of } \\
\text { children in shelter }\end{array}$ & $\begin{array}{l}\checkmark \quad \text { In the event of a case of domestic violence, if an application is made to } \\
\text { the head of a school with objective data, he or she shall recommend } \\
\text { that the victimized child is transferred to another school that is } \\
\text { designated by the education superintendent. } \\
\checkmark \text { The role of domestic violence-related institutions here is to make the } \\
\text { request to the head of a school to transfer or enroll the child. The } \\
\text { processs includes the submission of a "Verification report on domestic } \\
\text { violence victims" issued by the domestic violence counselling center, } \\
\text { the domestic violence shelter, and the Women's Emergency Hot Line. }\end{array}$ \\
\hline \multirow[t]{2}{*}{ Others } & $\begin{array}{l}\square \text { Other expenses provided by the government or local } \\
\text { goverments(necessary support such as living expenses, education }\end{array}$ \\
\hline & $\begin{array}{ll} & \text { support expense, etc.) } \\
\checkmark & \text { Regulation entrusted by other laws } \\
\checkmark & \text { All other assistance needed for the protection of victims, etc. }\end{array}$ \\
\hline
\end{tabular}

Source: The Ministry of Gender Equality and Family of Korea(2019, B).

Domestic violence shelters are classified as emergency shelters, short-term shelters, general shelters, family shelters, and long-term/ or disabled shelters. The victims need sufficient protection till they are ready to return to their homes or society. As of 2018, there were only four medium and long-term shelters in South Korea. The others were short-term shelters where the, victim could only stay for a limited period of time. However, rental houses were available at low prices for victims after they are discharged from the shelter. They could reside here for up to two to four years(The Ministry of Gender Equality and Family \& Women's Human Rights Institute of Korea, 2016). Currently, the protective assistance and period of stay of each domestic violence shelter is shown in Table 2.

Table 2: The protective subjects and period of allowed stay at each domestic violence shelter

\begin{tabular}{|c|c|}
\hline Emergency shelter & $\begin{array}{l}\checkmark \text { Victims of domestic violence, sexual violence, sex trafficking, and } \\
\text { abusive women and their children who urgently need meal and sleep } \\
\text { support, mental and physical stability, counselling, and treatment } \\
\checkmark \text { The principle aim is to provide protection for 3three days, though it can } \\
\text { be extended to seven days if necessary(after that, the victim is connected } \\
\text { to another protection facility). }\end{array}$ \\
\hline $\begin{array}{c}\text { A general } \\
\text { shelter(short-term) }\end{array}$ & $\begin{array}{ll}\checkmark & \text { Victims of domestic violence and their family members } \\
\checkmark & \text { Victims can live here for six months, and the period can be extended to } \\
& \text { three months more }\end{array}$ \\
\hline $\begin{array}{l}\text { A family shelter(short- } \\
\text { term) }\end{array}$ & $\begin{array}{l}\checkmark \text { Domestic violence victims and their family members may come in, but } \\
\text { first priority is given to violence victims with boys aged ten or older, the } \\
\text { second is domestic violence victims with children, and the third is } \\
\text { domestic violence victims } \\
\checkmark \text { Also, it can live here for six months, and the period can be extended to } \\
\text { three months more. }\end{array}$ \\
\hline
\end{tabular}




\section{8-20 October, 2019 BUDAPEST, HUNGARY}

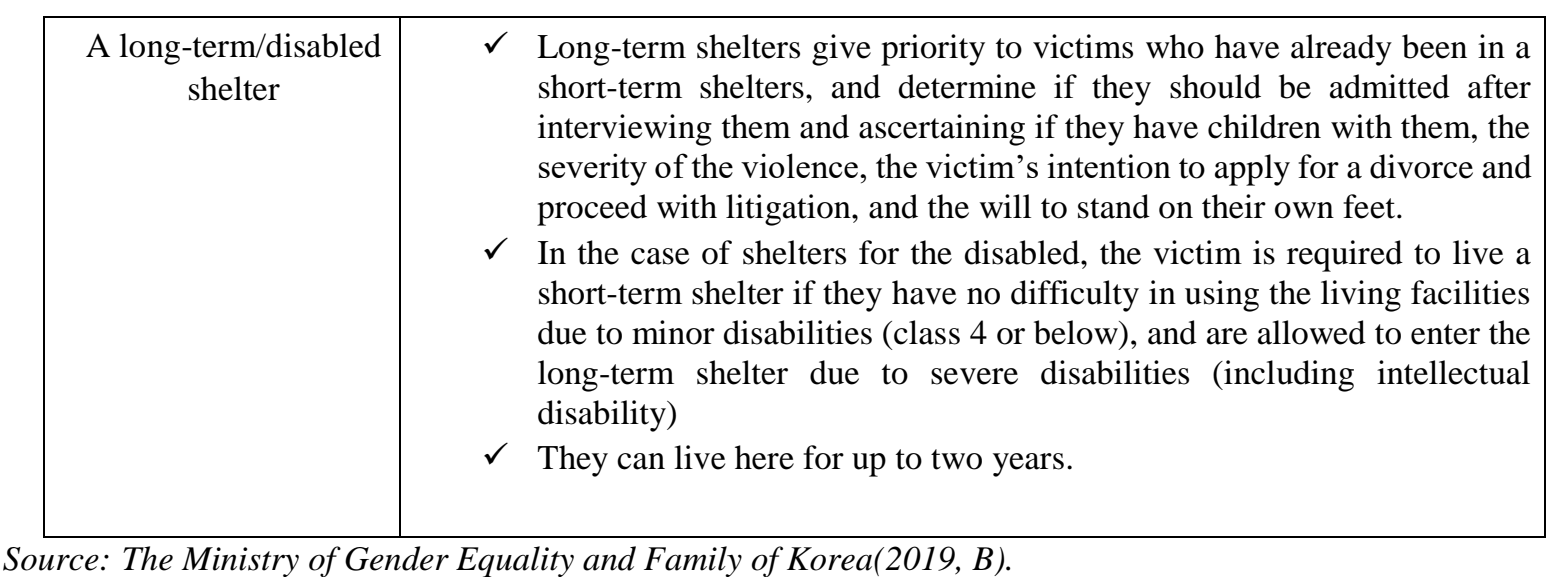

\subsubsection{Workers at domestic violence shelters in South Korea}

The Ministry of Gender Equality and Family in South Korea has guidelines for the number of workers at domestic violence shelters. A total of three workers, including one director and two counsellors, can work in a shelter of five to ten victims, while a total of four workers can work in a shelter of eleven to thirty victims, including one director and three counsellors, and a total of five workers can work in a shelter of more than thirty one victims, including one director and four counsellors. However, these shelters operate 24 hours a day without a break, and it is difficult for the workers to work for all 24 hours. Under these circumstances, a worker may have to support the victims of the shelter, and carry out administrative work at the same time.

In addition, workers at domestic violence shelters spend a lot of time with victims, watching and communicating closely with them and are therefore exposed to secondary trauma and threats(Jeong, 2010; 2012). Due to poor treatment, heavy work, secondary trauma, and various threats, the job satisfaction levels for these workers are low. The Ministry of Gender Equality and Family is trying to support workers by allowing them to use a part of the operating expenses to stop them from leaving work or counselling(The Ministry of Gender Equality and Family of Korea, 2019, B). However, it is important to note that their efficiency is low as the working conditions are not taken into account.

\section{Methods}

\subsection{Participants}

Participants of this study are workers at domestic violence shelters in Jeollabuk-do, South Korea. More areas could not be included as domestic violence shelters are sensitive to external exposure, which made it difficult to recruit participants. The participants were recruited through the director of each institutions. Six workers who voluntarily agreed to participate in the research were selected as final participants after they were given information regarding the purpose, contents and method of progress of the study. The characteristics of participants are listed in Table 3.

Table 3: General characteristics of participants in research

\begin{tabular}{|l|l|l|l|l|l|l|l|l|}
\hline Gender & Ages & Marital status & Children & $\begin{array}{c}\text { Type of } \\
\text { shelter }\end{array}$ & $\begin{array}{c}\text { Experience } \\
\text { at the } \\
\text { shelter }\end{array}$ & $\begin{array}{c}\text { Experience } \\
\text { of domestic } \\
\text { violence }\end{array}$ & reponsibility \\
\hline
\end{tabular}


World Conference on SOCIAL SCIENCES

\section{8-20 October, 2019 BUDAPEST, HUNGARY}

\begin{tabular}{|c|c|c|c|c|c|c|c|c|}
\hline A & Woman & Early 60s & Married & O & General & 7 & O & $\begin{array}{c}\text { Complete } \\
\text { support }\end{array}$ \\
\hline B & Woman & Late 40s & Married & O & General & 4 & $\mathrm{X}$ & $\begin{array}{c}\text { Accounting, } \\
\text { Job training }\end{array}$ \\
\hline C & Woman & Early 40s & Married & O & General & 3 & $\mathrm{X}$ & $\begin{array}{c}\text { Complete } \\
\text { support }\end{array}$ \\
\hline D & Woman & Early 30s & Married & $\mathrm{X}$ & Family & 7 & $\mathrm{X}$ & Child support \\
\hline E & Woman & Mid 30s & Marriage & O & Family & 5 & O & Accounting \\
\hline F & Woman & Late 40s & Divorce & O & Family & 7 & O & $\begin{array}{c}\text { Housing } \\
\text { support }\end{array}$ \\
\hline
\end{tabular}

\subsection{Data collection and analysis}

Data for this study was collected through one-on-one interviews scheduled from March to May 2019. The interviews were conducted in a comfortable environment. A comprehensive question like, "What are you experiencing as a worker at a domestic violence shelter?" was asked to begin the interview. Prior to the interview, the researcher once again informed the participants about the purpose of the research, privacy, and use of the research. The interview was conducted after the participant filled a consent form to participate in the study.

The data collected was examined by within-case and cross-case analysis of qualitative case studies. In the former, each participant's experience was analyzed in a personal context. In the latter, the semantics were extracted by integrating the experience of participants in the study, slating them into subcategories, and grouping them back into higher categories to find key topics.

\subsection{Ethical considerations}

This study was conducted on participants who were informed of the purpose and contents of the study and voluntarily expressed their willingness to participate. Before the interview, the researchers explained the research to the participants once again. The interview was recorded, and the interview could be interrupted or terminated at any time if the participants wanted to, or and they could ask questions if they needed to. Researchers also promised to exclude content that the participants did not want to disclose during interviews from the analysis and paid attention to the ensure that the participant's personal information is not exposed. The interview was conducted after the consent form was signed, and the study participants were paid a small remuneration.

\section{Results}

\subsection{Within-case}

A within-case analysis was performed to examine the individual contexts of the experiences of participants. The first participant, "'A" majored in infant education before getting married and after getting married focused only on the family. She had also studied theology, counselling, and social welfare, and experienced how the Women's Hot Line assists victims. After her child grew up, she realized that she was tired of simply being a home maker as a wife and mother, 
and had previously experienced domestic violence. At that point, she had benefitted from the positive energy and support offered by the Women's Hot Line. This made her realize that if she had been struggling with domestic violence, it would have been easier for her if someone would have reached out to her. As a result, she started working with the Hot Line and now supports the domestic violence victims at shelter.

Participant "'B" grew up seeing her grandmother mistreating her mother for not giving birth to a son. She felt that this was unfair as she could not understand why it was important to have a son and why should only the woman be held responsible for this. She then had an opportunity to work part-time on the Women's Hot Lines, and found that the values of the institution were in line with her belief. Later, she started working as a full-time worker at a domestic violence shelter and studied counselling to support the victims. She is now mainly in charge of accounting and job training.

Participant " C"” previously worked at a facility for the disabled for about ten years and happened to enter the current institution while she was looking for a new job. Although she was hesitant to work here because of the poor working conditions and low pay compared to her previous job, she decided to take up the position temporarily. At one point, she considered resigning as her life pattern was clearly different from what it was before and it was difficult to manage. Also, her children wanted her to quit the job. However, she continued to work as she felt a sense of mission and the work was rewarding, and consideration among workers. She currently supports the lives of domestic violence victims in the shelter.

Participant "'D"' majored in social welfare and had previously worked in the field of children and women's rights. She saw a job advertisement for a child-related worker at the Women's Hot Line, and she started got she position based on her prior experience. She was single when she started working with the institution. After working at the shelter, she found out that the children of victims of domestic violence also felt guilty for not being able to protect their mother. Seeing this, she decided not to have children after getting married.

Participant "'E" majored in health administration. While taking care of her grandmother with her mother, she realized that she liked to support people and take care of them. Hence, she started studying social welfare in preparation to get a job in that field. She was recommended to apply for a job at the Women's Hot Line through the labor office. In the beginning she mostly, worked in the office, but after sometimes she moved to a shelter. She is currently in charge of accounting and is trying to devise ways to support the victims as much as possible within the given budget.

Participant "'F", had experienced domestic violence and lived with her children at domestic violence shelters. At that time, she started working and got a job license. She left the shelter, due to the restrictions because of the rules and started working. As her life gradually stabilized, she applied for a divorce. She studied social welfare and counselling on the recommendation of the Women's Hot Line. She completed the necessary courses and started working as a domestic violence shelter worker. She is currently in charge of housing support, which is one of the support projects for domestic violence victims after they leave the shelter.

\subsection{Cross-cases}

Cross-case analysis resulted in nine topics: Empathy or an objective approach, Cause of conflict as well as arbitrator, Difficulty in being objective, Guilt for not providing enough support, 
Exposure to danger, Supporter or an obstruction, Poor work conditions and lack of respect, Motivation to work, and Facilitator of change.

\subsubsection{Empathy or an objective approach}

When some of the participants first met the victims of domestic violence, they said that they were shocked by the seriousness of the violence and felt sorry for the victims. Some participants confessed that they felt frustrated at why domestic violence victims were still being victimized, and were unable to find a way out of sooner, due to the low awareness of domestic violence in the beginning. On the other hand, some participants who themselves been victims, expressed sympathy by linking their experiences with those who they were helping. Some participants did not have any special thoughts as they did not have direct contact with the victims in the beginning.

\subsubsection{Cause of conflict as well as arbitrator}

To ensure smooth functioning, domestic violence shelters have detailed rules, hold family meetings, and coordinate necessary functions. However, conflicts between victims of various backgrounds are inevitable, and in the case of family shelters with children, conflicts between mothers lead to conflicts between children and vice versa. In serious cases, workers have to arbitrate conflicts, which the participants said is not an easy task. In shelters, conflicts not only occur between victims, but also between workers and victims. Sometimes, the excessive demands of victims' and aggressive behavior also creates conflicts. The participants were frustrated by the fact that they cannot respond strongly even in situations that could be dangerous.

\subsubsection{Difficulty in being objective}

Participants hear stories of serious domestic violence from the victims at the shelter, and they often see the physical impact (e.g., severe wounds). Participants who themselves have previously witnessed or experienced domestic violence confessed that it was difficult to maintain a proper emotional line while being sympathetic. The participants suffered secondary trauma such as not wanting to see violent images yet were continuously exposed to stories and photos of domestic violence. In addition, the victims displayed aggressive behaviour by projecting their experiences with domestic violence assailants to the workers, who said that due to this they experienced a lot of psychological exhaustion. Performance pressure, heavy administrative work, and the problem of not getting enough rest, made the situation even more difficult for them.

\subsubsection{Guilt for not providing enough support}

There is a limit to the support that can be offered to domestic violence victims. The victims who come to the shelter expect a lot of support and get angry when they cannot get the support from the workers and their expectations are not met. In this situation, the participants felt guilty that they could not offer the support and also blamed the environment. Some participants also expressed anxiety over the fact that they could not offer the support required and questioned if they were suitable for the work.

\subsubsection{Exposure to danger}

Some domestic violence assailant persistently pursue victims. One participant said that the assailant had once knocked on the door of the shelter and kept looking around. Another 
participant said that the assailant who spotted them while going out with the victim continued to chase them on the road, and with the help of the police, they managed to get out of the situation. There was also a participant narrated an incident when an assailant remembered her face and had spoken to her on the street. As such, victims and workers of domestic violence shelters are always exposed to danger and threatening situations.

\subsubsection{Supporter or an obstruction}

Active and appropriate cooperation from schools, police, and other related agencies is required to support the victim of domestic violence and their children. However, the participants said that related agencies were not always aware of the severity of domestic violence and did not take necessary measures in time, or that they could lead to the exposure of the victim. They also said that the workers were ignored in the process and this made it difficult for them.

\subsubsection{Poor work conditions and lack of respect}

The Participants accepted that the situation of the victims was so terrible that their own problems did not matter. While the workers have a sense of mission, but their treatment and working conditions were very poor. They do not get paid or treated well, and there are times they feel skeptical about why they should work under so much stress. The stressful and exhaustive working environment makes it even more difficult for the workers to perform well.

\subsubsection{Motivation to work}

The participants shared that the growth and independence of domestic violence victims was their motivation to continue the work despite poor conditions and psychological difficulties. When the victims who stayed in the shelter settled down with the help of the workers and their own efforts, they felt a sense of pride. Participants also said that not just the victims but even they personally evolved while working in the shelters.

\subsubsection{Facilitator of change}

While working at the shelter, some participants realized that they were victims of domestic violence before, or that there were other victims around them. Another participant realized that the issue of domestic violence was linked to the social structure and needed social intervention. Based on their own experiences, participants were revisiting issues that they had overlooked before, and actively expressing their opinion on the what they believed was wrong, and influencing the change in perceptions of their family and people around them.

\section{Conclusion}

For this study interviews were conducted with six workers at domestic violence shelters to look at their experiences in Jeollabuk-do, South Korea. As a result, nine topics were derived: Empathy or an objective approach, Cause of conflict as well as arbitrator, Difficulty in being objective, Guilt for not providing enough support, Exposure to danger, Supporter or an obstruction, Poor work conditions and lack of respect, Motivation to work, Facilitator of change. Suggestions based on the research result are as follows.

First, a system should be in place to ensure the safety of the workers as well as victims of domestic violence. While the worker plays a role in protecting victims in various situations, they also need to be protected because of the danger of exposure in shelters. Safety of workers 
should also be considered important, and safely measure to protect them from residents (victims) as well as assailants should be considered. For example, an emergency call number can be installed to deliver a simple message in the event of a dangerous situation (e.g., pressing ' 1 ' would indicate that police presence is required), or a provision should be made to ensure that a worker can respond fairly to a person who is in the shelter and threaten the worker.

Second, it is necessary to establish a system of smooth cooperation with agencies related to domestic violence. In particular, the police should be the most important facilitator in domestic violence cases, but participants in this study pointed out that they often have an uncooperative attitude. Measures should be sought to ensure that employees of related agencies have a better understanding of domestic violence and know the seriousness of the incident so that they can actively cooperate with the shelter. For example, a related agency should be subject to legal sanctions if it does not actively cooperate when necessary or exposes victims of domestic violence.

Third, a program is needed to address secondary trauma and exhaustion of workers at the shelter. Participants pointed out that it is sometimes difficult to participate in related programs, and that their schedules are too full and this makes it even harder for them. In addition, some workers may be forced to work all night at the shelter after attending the program during work hours. It is necessary to operate a program that can identify the working conditions and needs of workers different shelters and support them practically. As this is difficult in practice, it would also help to provide separate expense support for workers at shelters so that it can be used flexibly depending on the situation at each shelter. At the same time, care needs to be taken so that this does not lead to a reduction in basic operating costs and an increase in the workers support costs as the shelter's operating expense.

Fourth, it is necessary to improve the way the workers are treated and also the working conditions. At the moment, domestic violence shelters pay less than other social welfare institutions. Also, it is difficult for the workers to take a break and rest because of the working conditions. The low job satisfaction can have an impact the quality of service. It is imperative to improve the way workers are treated and the work environment.

This study has some limitations. First, this study only looked at the experiences of workers at domestic violence shelters located in Jeollabuk-do, South Korea. Although there are central guidelines for these shelters, the support offered differs based on regional polices. Follow-up studies will have to be conducted to compare the experience of workers in different regions. Next, participants in this study include only those who work in general and family-protected shelters. However, domestic violence shelters also include emergency shelters and long-term shelters, which need to be considered to understand the experiences of workers working in various types of shelters through follow-up studies. 


\section{References}

[1] Park, E. J. (2014). Construction of Mothering in the Context of Domestic Violence and Battered Women's Agency, Journal of Korean Women's Studies, vol. 30, pp. 173-212.

[2] Bae, Y. M. \& Seo, H. R. (2017). A narrative inquiry into helping experience of wife abuse survivors at battered women's shelters, Korean Journal of Qualitative Research in Social Welfare, vol. 11, pp. 31-58.

[3] So, B. S. \& Jeong, H. J. (2002). A Qualitative Study on Abuse Experience and Coping Behavior of Wives Staying in Shelter, Korean Journal of Family and Family Therapy, vol. 10, pp. 169-197.

[4] Yang, H. Y. \& Kim, H. S. (2009). Parenting Experience of the Mothers of Domestic Violence: Focused on the Shelter Residents, Korean Journal of Family Social Work, vol. 26, pp. 123-158.

[5] The Ministry of Gender Equality and Family of Korea. (2019, A). Performance of a Project to Support Victims of Domestic Violence in 2018.

[6] The Ministry of Gender Equality and Family of Korea. (2019, B). Guidelines for the Promotion of Women's and Children's Right in 2019.

[7] The Ministry of Gender Equality and Family of Korea \& Women's Human Rights Institute of Korea. (2016). Case Book to Support Domestic Violence Victims.

[8] Yoon, E. J. (2009). An Experiential Analysis of Burnout in Counsellors, Korean Journal of Counselling, vol. 10, pp. 1855-1871. 


\section{8-20 October, 2019 BUDAPEST, HUNGARY}

[9] Lee, E. J. (1997). Victims' Experiences of Wife-Abuse, Korean Journal of Women Health Nursing, vol. 3, pp. 250-267.

[10] Lee, J. Y. \& Yoo, K. R. (2010). Compassion Fatigue: Implications for Counsellors, Korean Journal of Counselling, vol. 11, 19-36.

[11] Lee, H. Y. \& Park, T. J. (2010). The experience of social exclusion in the context of domestic violence, Korean Journal of Women Studies, vol. 78, pp. 159-200.

[12] Jang, S. M. \& Kim, J. H. (2005). A Study on Battered Women's Experience in Calling the Police, Korean Journal of Family Social Work, pp. 127-160.

[13] Jeong. Y. J. (2010). Factors associated with secondary trauma among self-efficacy and client violence of workers in the field of counselling for female victims of violence: Focusing on the mediating effect of coping strategies, Doctoral dissertation, Chungnam National University, South Korea.

[14] Jeong. Y. J. (2012). A study of factors associated with burnout among workers in the field of counselling for female victims of violence, Korean Journal of Church Social Work, vol. 19, pp. 159-191.

[15] Jeong, H. Y. (2016). Secondary Traumatic Stress Felt by Practitioners in Counselling Center for Violence against Women on Burn-out: Focusing on mediating effects of selfeffects of self-efficiency and social support, Doctoral dissertation, Baekseok University, South Korea. 